\title{
FORGÁCSLEVÁLASZTÁSI SAJÁTOSSÁGOK TÖBBIRÁNYÚ ESZTERGÁLÁSKOR
}

\section{CHIP REMOVAL SPECIALITIES IN MULTI-DIRECTIONAL TURNING}

\author{
Ráczi Viktor ${ }^{1}$, Sipos Sándor ${ }^{2}$, Farkas Gabriella ${ }^{3}$ \\ ${ }^{1}$ Óbudai Egyetem, Bánki Donát Gépészmérnöki Kar, Anyag- és Gyártástudományi \\ Intézet, 1081 Magyarország, Budapest, Népszínház u. 8. 36-1-6665470, \\ raczi.viktor@bgk.uni-obuda.hu \\ 2 Óbudai Egyetem, Bánki Donát Gépészmérnöki Kar, Anyag- és Gyártástudományi \\ Intézet, 1081 Magyarország, Budapest, Népszínház u. 8. 36-1-6665427, \\ sipos.sandor@bgk.uni-obuda.hu \\ 3 Óbudai Egyetem, Bánki Donát Gépészmérnöki Kar, Anyag- és Gyártástudományi \\ Intézet, 1081 Magyarország, Budapest, Népszínház u. 8. 36-1-6665391, \\ farkas.gabriella@bgk.uni-obuda.hu
}

\begin{abstract}
For machining of increasingly complicated geometries, the longitudinal and transverse turning operations should be done with a single tool. Leading manufacturing companies have developed a number of constructions. The world's largest manufacturer has recently revolutionised turning by launching roughing and finishing tools. The roughing insert can work with "high feed turning" in four different directions of movement. This tool has a unique chip forming and removal, it forms a unique machined surface. The study gives an overview of the results, achieved in this area.
\end{abstract}

Keywords: multi-directional turning, PrimeTurning, new turning movements.

\section{Összefoglalás}

Az egyre bonyolultabb alkatrész-geometriák megmunkálásához a hossz- és keresztirányú esztergálást célszerű egyetlen szerszámmal elvégezni. A vezető gyártó cégek számos konstrukciót dolgoztak ki. A világ legnagyobb gyártója a közelmúltban egy nagyoló és egy simító szerszám piacra dobásával szinte forradalmasította az esztergálást. A nagyoló lapka „high feed turning” eljárással, négyféle mozgásirányban képes dolgozni. Ezen szerszámnak egyedi a forgácsképzése és leválasztása, csakúgy, mint a forgácsolt felület kialakítása. A tanulmány ezen a területen elért eredményeket tekinti át.

Kulcsszavak: többirányú esztergálás, PrimeTurning, újszerü esztergálási mozgás.

\section{Bevezetés}

$\mathrm{Az}$ egyre bonyolultabb alkatrészgeometriák megmunkálásához nem könnyü a megfelelő szerszám kiválasztása, ez kifejezetten időrabló feladat. Ha egyetlen szerszám elegendő a forgástestek hossz- és keresztirányú esztergálására, akkor nem csak a CNC-esztergák kihasználása javul a beállítási és állásidők mérséklődésével, hanem a szükséges kések száma (vagyis a felszerszámozás költsége), sőt a szükséges szerszámcsere-idő is csökken.

A többirányú esztergálás (MDT $=$ multidirectional turning) felszerszámozására a vezető gyártó cégek az évek során számos 
konstrukciót dolgoztak ki (lásd ISO1832 szabvány). Amennyiben a lapka csúcsszöge nagy (EPSR $\geq 80^{\circ}$ ), akkor az esztergálás csak hossz- és/vagy keresztirányban végezhető. Ha ez a szög $35 . . .60^{\circ}$ közötti, akkor már a kontúr is megmunkálható vele. Sikeresen alkalmazzák a beszúró/leszúró késekre emlékeztetö, hosszú és keskeny tollrésszel, a tartóba V-alakú rögzítéssel befogott egy vagy két végén használható lapkás változatokat is. Ezekkel beszúró, az azt követő hosszirányú, sőt kontúresztergálási feladatok is megvalósíthatók [1].

A világ vezető szerszámgyártója 2017 közepén jelent meg egy új elven müködő konstrukcióval, szinte forradalmasítva az esztergálást [2].

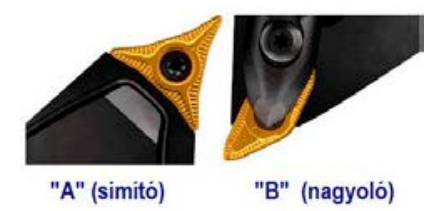

1. ábra. A PrimeTurning ${ }^{\mathrm{TM}}$ esztergálás kétféle szerszáma [2]

Az új elven müködő szerszámokat (1. ábra) megkülönböztető tulajdonságok a következők:

- az előtoló mozgás a tokmánytól a szegnyereg felé történik;

- a fogásra állás beszúrással kezdődik;

- a szerszám fóélszöge a szokásosnál sokkal kisebb $\left(\mathrm{KAPR}=25 \ldots 30^{\circ}\right)$.

\section{Forgácsolási tesztek „B” típusú PrimeTurning ${ }^{\mathrm{TM}}$ szerszámokkal}

A nagyoló esztergálási teszteket egy Dugard Eagle gyártmányú, BNC1840 jelü CNC-esztergán hajtottuk végre, a munkadarabot tokmányba fogva, csúccsal támasztva. A kísérleteknél hütő-kenő-öblítő közeget nem alkalmaztunk.

A kísérletekhez $\varnothing 60 \times 160 \mathrm{~mm}$ méretü, tokmányoldalon befogócsappal, a szegnyereg felől pedig központfuraton támasztott, $11 \mathrm{SMn} 30+\mathrm{C}$ anyagjelü, HB150 \pm 3 keménységü automata acél próbatesteket használtunk fel.

A forgácsolási tesztekhez a CP-25BR2525-11 jelủ késtartót és a CP-B1108-M5 4325 jelzésü (2. ábra) nagyoló lapkát alkalmaztuk.
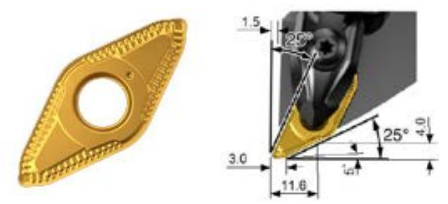

2. ábra. A CP-B1108-M5 4325 jelzésü lapka

A forgácsolási adatokat 3 , illetve 4 szinten változtattuk: a forgácsolósebességet $\mathrm{a}_{\mathrm{c}}=160 \ldots 250 \mathrm{~m} / \mathrm{min}$, a fogásmélységet $\mathrm{az} \mathrm{a}=0,5 \ldots 1,5 \mathrm{~mm}$ tartományban, míg az előtolást az $\mathrm{f}=0,3 \ldots 1,2 \mathrm{~mm}$ határok között állítottuk be (ez a „részleges faktoranalízis csúsztatott előtolásokkal" esete [3]).

\subsection{Forgácsképződés és erőhatások}

A megszokotthoz képest ellenkező irányban mozgó, KAPR $=25^{\circ}$ fóélszögü esztergakés sokkal vékonyabb és szélesebb forgácsot választ le, mint a hagyományos szerszámok. Az előtolás akár meg is kétszerezhetö: a lapka „high feed turning” módon, négyféle mozgásirányban képes dolgozni (a hagyományos előtolási irányban simítani képes). A „B” szerszámnak egyedi az élkialakítása (a fóél két különbözö élszögü részből áll, amelyet nagy rádiusz köt össze), ezért forgácsképzése különleges (3. ábra). Jól látható például, hogy a forgácstörőben elhelyezett osztóelemek rámásolódnak a forgácsra.

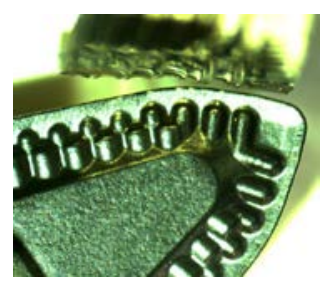

3. ábra. $A$, , $B$ ” jelü lapka és a forgács Körülmények: $a=1,5$ $\mathrm{mm} ; f=1,2 \mathrm{~mm}$ 
Ez a jellegzetesség természetesen kihat a felület minőségére is. A tízféle beállítással esztergált forgácsok tablója (4. ábra) azt mutatja, hogy nyolc esetben kaptunk kedvezően tört forgácsot, ám a legnagyobb forgácsolási adatok ( $\mathrm{a}=1,5 \mathrm{~mm}$ és $\mathrm{f}=1,2$ $\mathrm{mm}$ ) beállításakor veszélyesen tekeredő, gubancos forgács keletkezett.

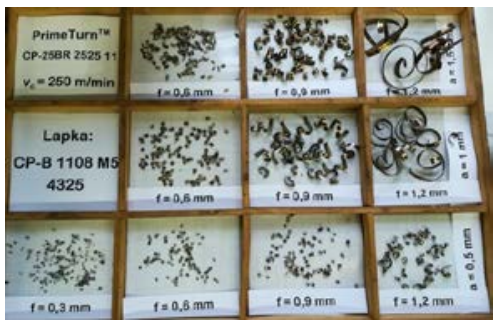

4. ábra. A leválasztott forgácsok tablója

A KISTLER 9021A típusú erőmérővel kapott és Dynoware szoftverrel kiértékelt átlagos erőösszetevők arról tanúskodnak, hogy az erőhatások jól modellezhetők az

$$
F_{i}=C_{F i} \cdot a^{y_{F_{i}}} \cdot f^{x_{F_{i}}}[\mathrm{~N}]
$$

függvénnyel, amelyben az $F_{c}, F_{f}$ és $F_{p}$ erőkomponenshez kétfaktoros regresszióval kiszámolt konstans $\left(\mathrm{C}_{\mathrm{Fi}}\right)$ és kitevők $\left(\mathrm{x}_{\mathrm{Fi}}, \mathrm{y}_{\mathrm{Fi}}\right)$ tartoznak (lásd 5. ábra).

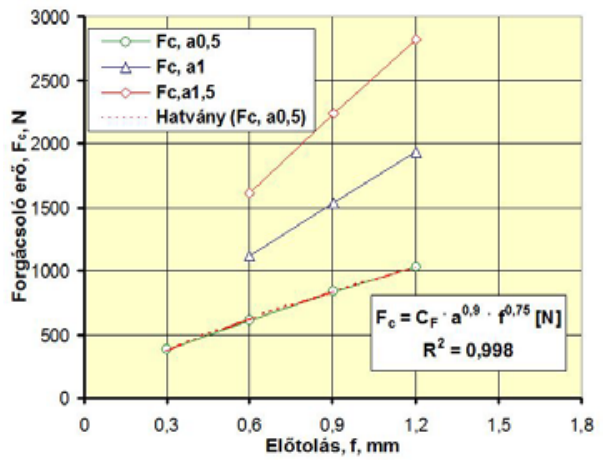

5. ábra. A forgácsolóerö alakulása és modellje

Az előtolóerő kicsiny, mindössze $10 . .20 \%$-a a forgácsolóerő értékének. Ez az arány a szokatlanul kis KAPR élszögnek tulajdonítható, csakúgy, mint a passzív erő kifejezetten nagy, $\mathrm{F}_{\mathrm{p}} / \mathrm{F}_{\mathrm{c}}=0,53 \ldots 0$,76 határok közötti viszonyszáma.

$\mathrm{Az} \mathrm{F}_{\mathrm{p}}$ döntő tényező a megmunkálási pontosság alakulásában is. A forgácsolás legnagyobb értékeinél ( $a=1,5 \mathrm{~mm}$ és $\mathrm{f}=1,2$ mm) a hordóssági hiba $\Delta \mathrm{D}=52 \mu \mathrm{m}$ volt, a maximum a szegnyereg felöli oldalon volt.

\subsection{Felületminőség}

Jelen anyagban csak az esztergált felület minőségének mikrogeometriai jellemzőit ismertetjük, a rétegtulajdonságokkal nem foglalkozunk [1].

A „B” típusú szerszámmal esztergált felület (szürt profiljának) Wt hullámossági értékei a 6. ábrán láthatók. Megállapítható, hogy a hullámosság főleg a fogásmélység hatására növekszik, az előtolásnak pedig f=0,9 mm beállításnál van optimális értéke.

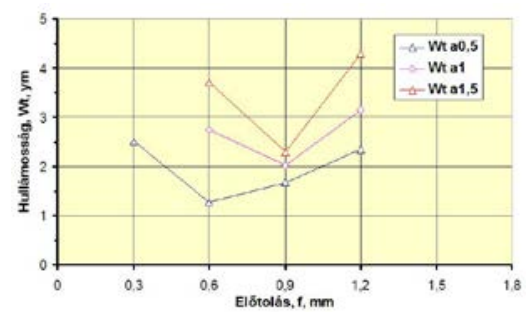

6. ábra. A hullámosság alakulása

Jóllehet, a nagyoláskor esztergált felületek érdessége szigorú követelményt nem jelent (általában $\mathrm{Rz} \leq 25 \mu \mathrm{m}$ ), az általunk alkalmazott beállításoknál mért érdességek alakulását a 7. ábra mutatja.

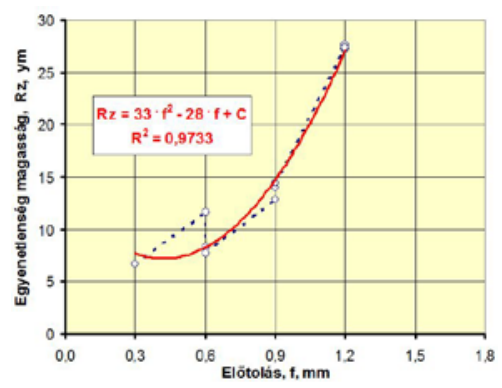

7. ábra. Az érdesség alakulása 
Megállapítható, hogy az élkialakítás miatt az érdesség számítására szolgáló (például az [1]-ben szereplő Bauer-féle) képletek egyike sem alkalmazható. Elönyös viszont az elötolásra felírt,

$$
R z=A \cdot f^{2}+B \cdot f+C[\mu \mathrm{m}]
$$

alakú egytényezős polinommodell.

Megjegyezzük, hogy mindig a nagyobb fogásmélységeknél mértük a kisebb $\mathrm{Rz}$ értékeket. Ennek az a magyarázata, hogy a radiális erő növekedése mintegy előfeszíti az esztergálás munkadarab-gép-szerszámrendszerét, ugyanakkor ez a jelenség axiális alakhibához és a felület fokozott hullámosságához vezet. Éppen ezért csak robusztus, merev darabok megmunkálása végezhető el a kis KAPR élszögü, „B” típusú szerszámokkal.

\subsection{Termelékenység}

A megnövelt előtolás intenzívebb (akár $450 \mathrm{~cm}^{3} / \mathrm{min}$ ) anyagleválasztást jelent, a gépi föidő zsugorodik, ennek következtében a termelékenység (db/óra) növekszik. Amennyiben kedvezően tört forgács keletkezik, akkor - a gépre vonatkozó teljesítménykorlátot figyelembe véve - a forgácsolósebesség növelhetö, ez pedig még inkább fokozza a gépkihasználást.

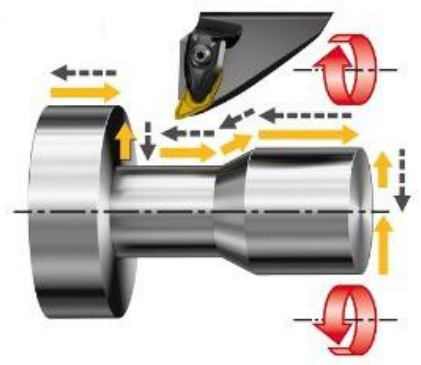

8. ábra. „ $B$ ” szerszám mozgásirányai (folyamatos: nagyolás, szaggatott: simítás)

Az ilyen típusú szerszám ellenkező előtolás- és forgásirányban, hagyományos elötolási értékekkel (simító üzemmódban) alkalmazható, akár kis kúposságú darabok (8. ábra) kontúresztergálásához is.

\section{3. Összegzés, további feladatok}

A forgácsolási tesztek bebizonyították, hogy a szerszám jól alkalmazható nagyolási feladatokhoz: a szokottnál kisebb élszögü eszköz megfelelöen stabil, megbízható a forgácsleválasztás, a lapka érdesség előállító-képessége is kedvező.

A passzív erő okozta rugalmas deformáció mind a próbadarabokon jelentkező méreteltérés, mind a felületminőség esetében a nagyolási pontosság szokásos tartományaiba esett. A „B” típusú szerszám azonban csak merev darabok esztergálására használható.

Az elvégzett vizsgálatok alatt a lapkán nem észlelhető kopás, mert a fellépő mechanikai és hőterhelés jól eloszlott a fogásban lévő szerszámél mentén.

Az adott megmunkálási feladathoz a viszonylag kis fogásmélységet megfelelően kompenzálja az emelt forgácsolósebesség, az (esetenként duplájára) növelt előtolás és néhány CAM-rendszer kódgenerátora. Ez utóbbi elengedhetetlen a nem szokványos mozgásciklusok megbízható tervezéséhez.

A további munkánk ki fog terjedni majd a különféle acélokon (beleértve a nehezen forgácsolható, korrózióálló minőségeken) végzendő vizsgálatokra, az egyes beállítási adatok korlátainak feltárására, valamint az 1. ábrán feltüntetett, simításra kifejlesztett szerszám hatékony felhasználásának vizsgálatára is.

\section{Szakirodalmi hivatkozások}

[1] dr. Sipos, S. - Dr. Palásti-Kovács, B. - Dr. Horváth, R.: Forgácsolótechnológiák és szerszámai, ÓE BGK3057, Budapest, 2015. p. 111-158.

[2] SandvikCoromant_PrimeTurningSCREEN_150_PPI, 2016.

[3] Iscar gyártmányú esztergalapkák komplex vizsgálata és minősítése, Kutatási jelentés, ÓE/BGK/AGI-GIT, Budapest, 2017. pp. 57. 